\title{
The problem of introduction of rare and endangered plants of the middle Urals' flora
}

\author{
M. Y. Karpukhin ${ }^{1}$, and A. V. Abramchuk ${ }^{1}$ \\ ${ }^{1}$ Ural State Agrarian University, 620075, Karl Libknekht str., 42, Yekaterinburg, Russia
}

\begin{abstract}
The problem of gene pool protection of wild plant species has gained a special relevance in modern times. In connection with the growth of population there is an increase in economic activity of human beings and their active influence on nature: wild lands plowing, overpasses plotting, construction of new and widening the boundaries of existing settlements. In addition, intensive harvesting of plants as medicinal, decorative, food, forage, etc is in progress. All this has a negative effect on the condition of wild plants: their stocks are declining, and some species are disappearing at all. A number of plants such as: spring adonis (Adonis vernalis L.), martagon lily [Liliumpilosisculum(Freyn)) Miscz,L.], butterfly orchid [Platantherabifolia(L.) Rchb], PaeoniaanomalaL. , rosewort (Rhodiolarosea L.) in their status, they belong to the group of rare and endangered species, they are listed in the Red Book of the Middle Urals, and their conservation requires introduction.

The study found that the species studied are culturally resistant, adapting well to new conditions. During the growth process, they went through all phenological phases, ending the development cycle with the fruiting phase with seed formation. Seeds with high enough sowing properties was provided by martagon lily, for which self-seeding is characteristic; low germination of seeds is noted in Rhodiolarosea L. and Platantherabifolia (L.) Rchb.
\end{abstract}

\section{Introduction}

In recent years, anthropogenic impacts on the environment have increased significantly: land plowing for crops, deforestation, bog reclamation, mining, fertilizers introduction, use of chemicals, etc., all this negatively affects the vegetation cover of the Urals and its surrounding areas, leads to the loss of genetic resources of the plant world [6]. Ranges of valuable plants are significantly reduced due to intensive collection of plants for medicinal, decorative, food, and other purposes. All this has a negative effect on the condition of wild plants: their stocks are depleting and some species are disappearing at all.

Plants such as: spring adonis (adonisvernalis L.), martagon lily (Liliumpilosisculum (Freyn) Miscz, L.], butterfly orchid (Platantherabifolia (L.) Rchb), paeoniaanomala (PaeoniaanomalaL.), rosewort (RhodiolaroseaL.) belong to a group of rare and endangered species, they are listed in the Red Book of the Middle Urals; Adonis vernalis L. and PaeoniaanomalaL. are also included in the Red Book of the Russian Federation [6]. Rare are the species represented by small populations growing in a relatively small area, 
introduction is necessary to preserve these plants. The Department of Plant Production and Breeding of the Ural SAU has been engaged in the introduction of these plants for many years $[2,4,10]$.

\section{Methods of research.}

The study on the rare and endangered plants introduction spread in the Middle Urals flora was carried out in the educational and experimental farm "Uralets", on the medicinal plants collection site of the Ural SAU. Soil type - heavy loamy podzolized chernozem. Reaction of soil medium is weakly acid ( $\mathrm{pH}$ salt extraction $-5,5)$; humus content $-7.1 \%$, cation exchange capacity - 32-35 mmol/100g; sum of exchange bases $27-30 \mathrm{mmol} / 100 \mathrm{~g}$. As a predecessor bare fallow was used, in autumn 2012 deep tillage (underwinter plowing to a depth of 25-27 $\mathrm{cm}$ ) was carried out. In the spring of 2013 the soil was cultivated and harrowed, after which the observed plants were planted in the open ground. Living plants were used. Wide row planting method was used: interrows width $-45 \mathrm{~cm}$; distance in row $-20 \mathrm{~cm}$. A total of 15 specimen of each species studied were planted.

Five species of plants listed in the Red Book of the Middle Urals were chosen as the object of the study: spring adonis(adonisvernalis L.), martagon lily [Liliumpilosisculum (Freyn) Miscz, L.], butterfly orchid [Platantherabifolia (L.) Rich.], paeoniaanomala (PaeoniaanomalaL.), rosewort (RhodiolaroseaL.).

The purpose of the study is to identify the possibility of introducing these plant species into the culture. The objectives of the study included the study of biometric indicators, phenological phases and timing of their passage, height dynamics and average daily growth of plants.

\section{Results of the study}

The plants selected for introduction belong to different botanical families and are significantly different in their morpho-biological indicators, such as: inflorescence type, flower color and size, leaf type, stem location, etc. (Table 1).

Table 1.Morpho-biological features of inflorescences and leaves of studied plants

\begin{tabular}{|c|c|c|c|c|}
\hline \multirow{2}{*}{$\begin{array}{l}\text { Type name, } \\
\text { family }\end{array}$} & \multicolumn{2}{|c|}{ Inflorescences (flowers) } & \multicolumn{2}{|c|}{ Leaves } \\
\hline & $\begin{array}{l}\text { inflorescence } \\
\text { type }\end{array}$ & $\begin{array}{l}\text { size of } \\
\text { flowers, cm; color }\end{array}$ & leaf type & $\begin{array}{l}\text { length, cm; } \\
\text { location on the } \\
\text { stem }\end{array}$ \\
\hline $\begin{array}{l}\text { 1. Adonis vernalis } \mathrm{L} \text {. } \\
\text { Buttercup }\end{array}$ & single, apical & $\begin{array}{l}5-6, \\
\text { golden yellow }\end{array}$ & $\begin{array}{l}\text { complex, sessile } \\
\text { finger-dissected }\end{array}$ & $\begin{array}{l}5-10, \\
\text { sequential }\end{array}$ \\
\hline $\begin{array}{l}\text { 2. Liliumpilosisculum } \\
\text { (Freyn) Miscz, (L.) } \\
\text { Liliaceae }\end{array}$ & rare, finite truss & $\begin{array}{l}\text { 3-4, } \\
\text { lilac-pink }\end{array}$ & $\begin{array}{l}\text { complex, stem } \\
\text { oblong- } \\
\text { lanceolate }\end{array}$ & $\begin{array}{l}\text { up to } 16 \text {, upper- } \\
\text { sequential; } \\
\text { middle and } \\
\text { lower in whorls }\end{array}$ \\
\hline $\begin{array}{l}3 . \\
\text { Platantherabifolia }(\mathrm{L} .) \\
\text { Rich. } \\
\text { Orchidaceae }\end{array}$ & $\begin{array}{l}\text { multi-flower } \\
\text { cylindrical ear }\end{array}$ & $\begin{array}{l}0.7-1.2, \\
\text { white, at the ends } \\
\text { slightly greenish } \\
\text { petals }\end{array}$ & $\begin{array}{l}\text { simple, oblong, } \\
\text { narrowed into } \\
\text { winged petiole }\end{array}$ & $\begin{array}{l}\text { 8-18, } 2 \text { leaves } \\
\text { converging, } \\
\text { almost suprotive }\end{array}$ \\
\hline $\begin{array}{l}\text { 4. PaeoniaanomalaL. } \\
\text { Paeoniaceae }\end{array}$ & $\begin{array}{l}\text { single, located } \\
\text { on top of the } \\
\text { stem }\end{array}$ & $\begin{array}{l}\text { 8-13, } \\
\text { purple-pink }\end{array}$ & $\begin{array}{l}\text { complex, } \\
\text { twin-triple- } \\
\text { dissected }\end{array}$ & $\begin{array}{l}10-30, \\
\text { stem, sequential }\end{array}$ \\
\hline
\end{tabular}




\begin{tabular}{|l|l|l|l|l|}
\hline $\begin{array}{l}\text { 5. Rhodiolarosea } \text { L. } \\
\text { Crassulaceae }\end{array}$ & $\begin{array}{l}\text { corymbose, } \\
\text { multi-flower }\end{array}$ & $\begin{array}{l}\text { small, golden } \\
\text { yellow, sepals, up } \\
\text { to 2 mm long }\end{array}$ & $\begin{array}{l}\text { simple, oblong- } \\
\text { ovate }\end{array}$ & $\begin{array}{l}1-3.5 ; \\
\text { sedentary }\end{array}$ \\
\hline
\end{tabular}

Spring adonis- Adonis vernalis L., buttercup family (RanunculaceaeJuss). Adonis is distributed in the middle and southern (Crimea) region of the European part of Russia, in Siberia. In the Middle Urals it is found in the southeastern part of Sverdlovsk Oblast: in Irbit, Kamyshlov, Arti districts. Ecologically and phytocenotically, spring adonis is mainly correlated with stepped meadows with xero-mesophilic herb diversity. It is found on the edges of deciduous forests, dry slopes of southern orientations, less often in steppes with Festúcavalesiáca and Stipa $[1,4]$.

Spring adonis is included in the Red Book of Russia and the Middle Urals. Status Category III. Rare species. Presented by small populations that have narrow ecological amplitude. To preserve its ranges it is necessary to create reserves with strict observance of protection measures, as well as introduction of this species $[1,6,9]$.

The biologically active substances contained in adonis belong to various chemical groups. All organs of the plant contain cardiac glycosides. They are mostly contained in root systems, but only overground shoots should be used to preserve the species: stems, leaves, and flowers. Flavonoids, saponins, phytosterol, adonite alcohol have been found in the herb; roots and seeds contain cardiac glycosides and coumarin $[5,7,8]$.

For medical purposes, the overground part of the plant is harvested, cutting the grass with a sharp knife at a height of $5-10 \mathrm{~cm}$ from the soil surface. When the stems are cut below this level, the plants do not resume and even partially die off. The full collection of all stems from the bush is unacceptable, as the formation of the renewal buds is disrupted. In natural conditions, to preserve adonis populations 1-2 well-developed bushes must be left for every $100 \mathrm{~m} 2$. Stocking in the same place can be carried out no more than once every 2-3 years $[1,8,11]$.

Preparations derived from spring adonis are widely used in the treatment of cardiovascular diseases, insomnia, increased nervous excitability, heart swelling. The main action is cardiotonic, diuretic and moderately sedative.

Adonis is a valuable decorative plant. It blooms early in spring and in summer it forms openwork, patterned leaves, giving plants high decorativity [3]. Adonis is widely used in landscape design, looks good in group plantings or among rarely planted shrubs, as well as on stony slides of southern expositions.

Spring adonis prefers places protected from cold winds and well warmed by the sun; soils loose, cultured, with a neutral reaction of the medium. In the first 2-3 years it develops slowly, so it is heavily clogged with weed plants. Requires frequent weeding, gives well response for feeding, irrigation and hoeing [2].

Martagon lily, the martagon is Liliumpilosisculum (Freyn) Miscz,( L.). Liliaceae family -LiliaceaeJuss. Rare (Eurasian boreal) species, listed in the Red Book of the Middle Urals. In the Urals occurs infrequently, solitary or in small groups in sparse coniferous, mixed and deciduous forests, is protected in the Visim Nature Reserve [1,9].

Bulbs contain vitamins, mucus, carbohydrates. Bulbs are prepared after the end of growing (September). In ethnomedicine, lily is known as a medicine for many diseases. Bulb infusions are used as wound-healing, anti-inflammatory, diuretic, sedative remedies. Flower infusion is used in treatment of gallbladder diseases. Leaves and juice have woundhealing effects. Melliferous plant. Dyeing, paints the wool black. Bulbs in raw and dried form are used in food. Decorative plant.

In 2013, martagon lily bulbs from the natural population (mesophilic mixed forest) were transferred to the culture to study its adaptation to new growing conditions. Table 2 
provides biometric indicators, which show that martagon lily is easily introduced into the culture with all biometric characteristics significantly better than in natural populations.

Table 2.Biometric features of martagon lily growing in different environmental conditions (on average for 2013-2019)

\begin{tabular}{|c|c|c|}
\hline \multirow{2}{*}{ Biometric indicators } & \multicolumn{2}{|c|}{ Growing conditions } \\
\cline { 2 - 3 } & in natural population & in culture \\
\cline { 2 - 3 } Stem: & $75-128$ & $148-174$ \\
height, cm & $0.5-0.8$ & $1.1-1.3$ \\
\hline diameter (near soil surface), cm & $1-2$ & $5-7$ \\
\hline Leaves (number, pcs.): & $2-4$ & $1-2$ \\
full whorls (8 to 17 leaves) & $8-12$ & $10-24$ \\
false whorls (3-4 leaves) & & $39-45$ \\
sequential leaves & $15-17$ & $17-23$ \\
\hline Inflorescence: & $4-6$ & \\
\hline length of flower truss, cm & & -0.6 \\
number of flowers in inflorescence, \\
pcs.
\end{tabular}

Butterfly orchid - Platantherabifolia(L.) Rich. Orchidaceae family - OrchidaceaeJuss. It is distributed in Europe, West and Minor Asia. It is found in the European part of Russia, southern regions of Siberia in mixed forests, on wetland habitats, forest glades.

In the Middle Urals it grows in moist deciduous and mixed forests, in forest meadows, sometimes in wetland light forests. It is found from the Southern to the Subarctic Urals. The species is included in the Red Book of the Middle Urals, protected in the territory of many nature monuments and reserves [6,9].

Young tubers contain mucus (up to 50\%) consisting mainly of protein substances (up to $15 \%$ ); sugar (up to 1\%), starch (about 27\%), small amounts of oxalic acid calcium, coumarin, mineral salts, traces of essential oil and alkaloids [5].

Only young tubers are prepared during flowering or at its end (in June-July), while the peduncles are preserved. In medicinal properties, the butterfly orchid is close to the military orchid. Dried root tubers (tubera) have anti-inflammatory, antiseptic, fortifying, tonic, anticonvulsant effects [8]. It is used in treating gastrointestinal diseases. It is recommended for overall strengthening in elderly or disease-emaciated individuals. The herbal infusion is used as a diuretic, sweaturetic and hypotensive agent.

The decorative plant is called "wild orchid", flowers have a strong aroma intensifying by evening; can be used to decorate alpine slides of northern exposition, coastal zone water bodies [3].

Paeoniaanomala - PaeoniaanomalaL. Paeoniaceae family - PaeoniaceaeRudolphi. A rare, endangered species included in the Red Book of the Russian Federation. About 40 species of this genus are known, which are distributed mainly in the Northern hemisphere, there are about 20 species in the Russian Federation.

It grows in non-dense coniferous and deciduous forests, in high-grass and taiga meadows, edges and forest clearings. It is most common in mountains, light forests near the upper limit of forest cover. In wild form, paeoniaanomala is found in southern Europe, eastern Asia, and the West of North America.

In our country paeoniaanomala is widespread in Siberia, much less common in the European part of Russia. In the Middle Urals sporadically grows in the territory from the Southern to the Subarctic Urals. In the mountain forest belt, paeoniaanomala is correlated to coastal meadow slides and light forests, in the foothills or on the plains - to river valleys $[1,6,9]$. 
Up to $1.6 \%$ of essential oil was found in the roots of the plant, which includes peonol, methylsalicylate, benzoic and salicylic acids; glycoside salicin, traces of alkaloids, proteins, tannins (up to $8.8 \%$ ), flavonoids (up to $1.39 \%$ ), saponins. Of non-specific active substances - starch (up to $78 \%$ ), sugar (up to $10 \%$ ). In the overground part - tannins, flavonoids. Fatty oil (up to $41.1 \%$ ), which includes glycerides of oleic, linoleic and linolenic acids is found in the seeds [10].

Paeoniaanomala grass, as well as rhizomes and roots, are used as medicinal raw materials. The grass is harvested during flowering period, underground organs - at the end of vegetation. In the experiment, preparations reduce blood pressure, have bactericidal, analgesic, anti-inflammatory, anticonvulsant, soothing, phytoncid effects. Tincture of paeonia roots is used in diseases of the cardiovascular system, insomnia.

Melliferous plant. In Siberia, the roots are eaten as a seasoning to meat dishes. Used in the production of the "Baikal" beverage. Roots in toasted form is used as tea substitute. Decorative, it should be more widely introduced in the range of decorative plants.

Rosewort, golden root - RhodiolaroseaL. The stonecrop family - Crassulaceae DC. Rosewort has a wide Eurasian arcto-highland range. It is found in the mountains of Western Europe (Alps, Carpathians), Western Siberia (Altai, Sayany), Eastern Siberia (Yakutia), Far East including Sakhalin and Kamchatka. It grows in the Arctic region, the highland belt, alpine and subalpine meadows, rocky and rubble slopes. On the territory of Russia, the main center of this species' distribution are the mountains of Southern Siberia: Altai, Kuznetsk Alatau, Western and Eastern Sayany, Tuva Mountains. The plant is mainly spread in the subalpine and lower part of the alpine belts. Streek and river valleys and moist highland meadows serve as the optimum habitats of rosewort. In alpine high terrain conditions, the plant appears up to 2300-2400 m above sea level.

In the Middle Urals, rosewort is common in mountain tundra and on bald mountains, stony slopes and rock slides in the Ivdelsk foothill district $[2,4]$. It occurs on wet, welldrained areas; soils are light, sabulous or rubbly [1.9]. Status - Category III. A rare species with declining numbers and disjointed range.

It is protected in the reserve "DenezhkinKamen' ", in the territory of natural monuments: "Serebryansky Cross" (Serebryansky Ridge), rocks on the Chusovaya river.

Rosewort refers to highly effective medicinal plants [5,8]. Roots and rhizomes of rosewort contain tannins (up to $20 \%$ ), anthraglycosides, essential oil, organic acids (citric, oxalic, malic, amber), phenolic acids (trioxybenzoic, caffeic, chlorogenic, ferulic), significant amounts of sugars, proteins, fats, waxes, sterols, glycosides, flavonoids, and large amounts of manganese. The main active substances of the plant's roots are phenolalcoholtyrosol and its glycoside salidroside (rhodioloside) [5]. In recent years, a high antioxidant effect and antitumor activity of Rosewort has been established [11,12]. Rosewort normalizes metabolic processes, promotes economical consumption of energy resources and rapid resynthesis, improves energy metabolism in muscles and brain due to oxidative processes. Rosewort preparations have a stimulating effect on mental performance.

People of many countries are known to eat leaves, the overground part of rosewort, for food. Gentle young shoots and leaves cut to bloom are recommended for preparing a vitamin salad. The underground part is used in the food industry to make non-alcoholic tonic beverages. A tonic beverage "Golden Altai" was obtained from the golden root. Rosewort can be used in landscape design in the design of alpine slides, it forms beautiful mats of golden yellow flowers [3]. Great melliferous plant.

In the experiment, the growth dynamics and average daily growth of the studied plants were observed. The data shown in table 3 shows that the height of plants in the culture is much higher than the natural growth conditions. The maximum average daily increase in studied plants was observed at different times: spring adonis - in mid-May, paeoniaanomala 
- at the end of May; martagon lily - in I- II decades of June; butterfly orchid and rosewort — in the 1st decade of June. The high average daily increase is noted in martagon lily, its value in 2019 ranged from 1.0 to $5.85 \mathrm{~cm}$. The average height of martagon lily plants by the end of June reached $148 \mathrm{~cm}$.

Table 3.Dynamics of height and average daily growth, 2019.

\begin{tabular}{|c|c|c|c|c|c|c|c|c|c|}
\hline \multirow{3}{*}{ Plant species } & \multirow{3}{*}{ Indicators, $\mathrm{cm}$} & \multicolumn{8}{|c|}{ Accounting dates } \\
\hline & & \multicolumn{4}{|c|}{ May } & \multicolumn{4}{|c|}{ June } \\
\hline & & 7 & 14 & 21 & 28 & 4 & 11 & 18 & 25 \\
\hline \multirow{2}{*}{ 1. Adonis vernalis L. } & height & 5 & 15 & 20 & 28 & 35 & 42 & 45 & 45 \\
\hline & $\begin{array}{l}\text { average daily } \\
\text { growth }\end{array}$ & - & 1.43 & 0.71 & 1.14 & 1.0 & 1.0 & 0.43 & - \\
\hline \multirow{2}{*}{$\begin{array}{l}2 . \\
\text { Liliumpilosisculum } \\
\text { (Freyn) Miscz, L. }\end{array}$} & height & - & 5 & 12 & 30 & 58 & 89 & 130 & 148 \\
\hline & $\begin{array}{l}\text { average daily } \\
\text { growth }\end{array}$ & - & - & 1.0 & 2.57 & 4.0 & 4.43 & 5.85 & 2.57 \\
\hline \multirow{2}{*}{$\begin{array}{l}3 . \\
\text { Platantherabifolia }(\mathrm{L} \\
\text {.) Rich. }\end{array}$} & height & 2 & 5 & 8 & 11 & 27 & 35 & 35 & 35 \\
\hline & $\begin{array}{l}\text { average daily } \\
\text { growth }\end{array}$ & - & 0.43 & 0.43 & 0.43 & 2.28 & 1.14 & - & - \\
\hline \multirow{2}{*}{$\begin{array}{l}4 . \\
\text { PaeoniaanomalaL. }\end{array}$} & height & 10 & 25 & 37 & 55 & 67 & 75 & 82 & 84 \\
\hline & $\begin{array}{l}\text { average daily } \\
\text { growth }\end{array}$ & - & 2.14 & 1.71 & 2.57 & 1.71 & 1.14 & 1.0 & 0.29 \\
\hline \multirow{2}{*}{ 5. Rhodiolarosea L. } & height & 5 & 8 & 12 & 18 & 27 & 36 & 40 & 42 \\
\hline & $\begin{array}{l}\text { average daily } \\
\text { growth }\end{array}$ & - & 0.43 & 0.57 & 0.86 & 1.29 & 1.28 & 0.57 & 0.29 \\
\hline
\end{tabular}

During the study, observations were made on phenological phases and the timing of their passage. From the data shown in table 4, it is evident that early spring regrowth is characteristic of rosewort. Spring regrowth in adonis was observed 5 days later,

Table 4. Phenological phases and timing of their passage 2019

\begin{tabular}{|l|c|l|l|l|l|}
\hline \multirow{2}{*}{$\begin{array}{c}\text { Phenological } \\
\text { phases }\end{array}$} & \multicolumn{5}{|c|}{ Plant species } \\
\cline { 2 - 6 } & 1. Adonis \\
vernalis L. & $\begin{array}{l}\text { 2. } \\
\text { Liliumpilosi } \\
\text { sculum } \\
\text { (Freyn) } \\
\text { Miscz, L. }\end{array}$ & $\begin{array}{l}\text { 3. } \\
\text { Platanthera } \\
\text { bifolia(L.) } \\
\text { Rich. }\end{array}$ & $\begin{array}{l}\text { 4. } \\
\text { Paeoniaano } \\
\text { malaL. }\end{array}$ & $\begin{array}{l}\text { } \\
\text { Rhodiolarosea } \\
\text { L. }\end{array}$ \\
\hline 1. Spring regrowth & 3.05 & 10.05 & 7.05 & 3.05 & 29.04 \\
\hline 2. Budding & 7.05 & 4.06 & 21.05 & 21.05 & 14.05 \\
\hline $\begin{array}{l}\text { 3. Flowering: } \\
\text { beginning }\end{array}$ & 14.05 & 18.06 & 4.06 & 28.05 & 21.05 \\
\hline massive & 21.05 & 25.06 & 11.06 & 4.06 & 28.05 \\
\hline
\end{tabular}




\begin{tabular}{|l|c|c|c|c|c|}
\hline $\begin{array}{l}\text { 4. Fruiting: } \\
\text { beginning }\end{array}$ & 28.05 & 1.07 & 18.06 & 11.06 & 4.06 \\
\hline massive & 4.06 & 8.07 & 25.06 & 18.06 & 11.06 \\
\hline
\end{tabular}

than in rosewort, the transition to the generative stage of development was observed in the first decade of May. In 2019, the budding phase came on May 7. It should be noted that adonis buds appear on the soil surface almost simultaneously with the first leaves, the height of plants at this time does not exceed $5-7 \mathrm{~cm}$; the beginning of flowering - the second decade of May. More later development is noted in martagon lily.

\section{Conclusion}

The analysis of the obtained results makes it possible to conclude that the studied species are resistant in culture, they have shown good adaptability to new conditions. In the experiment, the plants underwent all phenological phases, ending the development cycle with the fruiting phase. During the period of observation, only martagon lily formed seeds with quite high sowing qualities, self-seeding was noted; in other species self-seeding was not present.

\section{References}

1. A.V. Abramchuk, S. K. Mingalev, Cultivated medicinal plants. Range, properties, technology of cultivation, 292 (Yekaterinburg,Fascimile of EMA Education and Methodics Association of Universities of the Russian Federation, 2004)

2. A.V. Abramchuk, Effect of growing space on growth and development of rosewort, Rational use of natural and biological resources in agriculture, 3-5 (2014)

3. A.V. Abramchuk, S. K. Mingalev, M. Y. Karpukhin, G. G. Kartasheva, Landscape design. Features of creation of stony and water gardens, 362(Yekaterinburg, Publishing House of the Ural SAA, 2012)

4. A.V. Abramchuk, Journal of Biotechnology, 3 (2018)

5. T.A. Goncharova, Encyclopedia of Medicinal Plants, 1, 560, 2, 528 (M.: Publishing House MSP, 2001)

6. P. L. Gorchakovsky, A.V. Abramchuk, P. L. Gorchakovsky, Fundamentals of protection and ecological monitoring of meadow vegetation, Productivity of hayfields and pastures, 25-29 (Novosibirsk, 1986)

7. Large illustrated encyclopedia. Medicinal plants, 224 (Saint Petersburg, NBSEA, 2017)

8. All about medicinal plants, 192 (St. Petersburg, "NBSEA" LLC, 2016)

9. Red Book of the Middle Urals (Sverdlovsk and Perm regions): Rare and endangered species of animals and plants, 279 (Yekaterinburg, Publishing house of the Ural University, 1996)

10. S.K. Mingalev, O.V. Brusnitsyna Agrarian Education and Science, 1(2019)

11. Kosakowska, O., Bączek, K., Przybył, J.L., et al., Dry Extracts. (Basel, Switzerland), 23 (7) (2018)

12. Xu. Y. Jiang, H. Sun C., Yu, J., Xu, X., International Journal of Biological Macromolecules, 117, 167-178 (2018)

13. M. Grech-Baran., K. Sykłowska-Baranek, A. Pietrosiuk, Phytochemistry reviews, 14, 657-674 (2015)

14. Li. Y. Pham, V. Bui, M., et al., Current Pharmacology Reports, 3 (6), 384-395 (2017)

15. A. Coors, M. Brosch, E. Kahl, B. Gerber, Journal of Ethnopharmacology, 235, 320-328 (2019) 
16. D.I. Ivanova, S.S. Boyadzieva, G. Angelov, et al., Bulgarian Chemical Communications, 50, 151-157 (2018) 